\title{
A LEITURA LITERÁRIA DOS DETERMINANTES PRESENTES NA OBRA A METAMORFOSE DE KAFKA
}

Rosangela Miola Galvão ${ }^{1}$

Sandra Aparecida Pires Franco ${ }^{2}$

\begin{abstract}
RESUMO: Esta pesquisa buscou contribuir com a Leitura Literária da obra $A$ metamorfose de Franz Kafka no que concerne ao desvelamento dos determinantes presentes no discurso do autor. Nota-se que grande parte dos leitores realiza uma leitura superficial das obras literárias, ato que prejudica o entendimento da obra como um todo, por isto a importância deste tipo de pesquisa para a área da Educação. A base teórica para a análise foi o Materialismo Histórico e Dialético. A metodologia consistiu na observação de frases dentro do texto e a relação que as mesmas possuem com os determinantes do discurso, assim como a influência desses na totalidade de compreensão da obra. A obra $A$ metamorfose representa um marco referencial na Literatura ao questionar a submissão do ser humano ao capital, que interfere diretamente nas relações sociais.
\end{abstract}

Palavras-chave: Leitura. Linguagem Literária. Materialismo.

\section{THE LITERARY READING OF THE DETERMINANTS PRESENT IN THE WORK METAMORPHOSIS OF KAFKA}

\begin{abstract}
This research sought to contribute to the Literary Reading of Franz Kafka's work The metamorphosis regarding the unveiling of the determinants present in the author's discourse. It is noteworthy that most of the readers make a superficial reading of the literary works, which harms the understanding of the work, therefore the importance of this type of research for the Education area. The theoretical basis for the analysis was Historical and Dialectical Materialism. The methodology consisted in the observation of phrases within the text and the relation that it has with the determinants of the discourse, as well as their influence in the totality of understanding of the work. The metamorphosis represents a landmark in Literature when questioning the submission of the human being to capital that directly interferes in social relations.
\end{abstract}

Keywords: Reading. Literary Language. Materialism.

\footnotetext{
${ }^{1}$ Mestre em Educação. Doutoranda em Educação pela Universidade Estadual de Londrina. Londrina-PR/Brasil. E-mail: rmgalvao2012letras@gmail.com.

2 Doutora em Letras. Professora da Universidade Estadual de Londrina (UEL). Londrina-PR/Brasil. E-mail: sandrafranco26@hotmail.com.
} 


\section{LA LECTURA LITERARIA DE LOS DETERMINANTES PRESENTES EN LA OBRA LA METAMORFOSIS DE KAFKA}

RESUMEN: Esta investigación buscó contribuir con la Lectura Literaria de la obra La metamorfosis de Franz Kafka en lo que concierne al desvelamiento de los determinantes presentes en el discurso del autor. Se nota que gran parte de los lectores realiza una lectura superficial de las obras literarias que perjudica el entendimiento de la obra como un todo, por esto la importancia de este tipo de investigación para el área de la Educación. La base teórica para el análisis fue el Materialismo Histórico y Dialéctico. La metodología consistió en la observación de frases dentro del texto y la relación que la misma posee con los determinantes del discurso y la influencia de éstos en la totalidad de entendimiento de la obra. La obra La metamorfosis representa un marco referencial en la Literatura al cuestionar la sumisión del ser humano al capital, que interfiere directamente en las relaciones sociales.

Palabras clave: Lectura. Lenguaje Literaria. Materialismo.

O estudo das contribuições da Leitura Literária para a área da Educação se mostra importante sobretudo se forem consideradas as dificuldades dos estudantes na leitura dos textos, pois a compreensão dos discursos interfere diretamente na apropriação dos conhecimentos em diferentes disciplinas na escola, bem como, no desenvolvimento psíquico do homem. A história A metamorfose, do escritor tcheco Franz Kafka, foi escrita em alemão, língua adotada pelo autor e utilizada para a produção de outras obras lançadas ao público postumamente. Escrita por volta de 1906, segundo estudiosos do autor, o filólogo tcheco Josef Cermak, a diretora da sociedade Franz Kafka, Merketa Malisova, bem como o professor e escritor Modesto Carone, a obra A metamorfose teve sua primeira edição em 1915.

Traduzida em vários idiomas, a obra possui repercussão mundial. Observa-se que as inúmeras capas ilustrativas, criadas até o momento, buscam conciliar o absurdo presente na história com a visão estarrecida do leitor aos fatos que são objetivamente narrados pelo autor em terceira pessoa. Pode-se considerar que a obra é de fácil leitura, no entanto, as palavras trazem muito mais que a simples descrição realista dos fatos, pois a sobriedade das frases questiona o comportamento do ser humano diante das amarguras da vida.

Ao transcender ao contexto de produção, de uma obra do século XX, o autor parece descrever situações do nosso cotidiano, nas quais os relacionamentos são baseados no interesse, com o sentimento de utilidade, ou seja, com a utilização proveitosa de alguém. 
Pode-se considerar que Kafka insere nos termos utilizados um pouco de si, dos seus próprios anseios, ou ainda, daquilo que o homem busca agora, um sentido para a vida.

Ao transpor o leitor ao universo do fantástico, Kafka busca questionar a sociedade da qual participa, a realidade capitalista e suas relações com a mão de obra. Para entender esse cenário e aprofundarmos o conhecimento da obra A metamorfose, a pesquisa, no primeiro momento, apresenta a Leitura Literária e sua importância na vertente do materialismo. No segundo momento, a pesquisa traz os trechos mais significativos da obra, considerando o contexto de produção, o histórico do autor, e qual a influência de ambos na obra, para que o leitor possa ter uma visão do conjunto dessa novela.

O terceiro e último momento da pesquisa constitui-se na apresentação dos determinantes presentes na obra e suas contribuições para entender os entrelaces da história, além de perceber as influências do momento histórico-social de produção da obra na vida dos personagens. Vale ressaltar alguns trabalhos realizados nessa perspectiva que produziram melhorias significativas na leitura de textos dos estudantes ao trabalhar com projetos de intervenção para a análise dos determinantes nos textos, dentre eles: Franco e Oliveira (2016), Franco e Fernandes (2017) e Galvão et al. (2016).

\section{A leitura literária}

A pesquisa objetiva apresentar a visão de autores materialistas acerca da importância da Leitura Literária para o desenvolvimento histórico-cultural do homem, em especial, para o papel do autor, da obra e do leitor no momento de interpretação da obra, assim como o contexto de produção e leitura da história. Para Candido (2008), a leitura de uma obra literária necessita abranger o questionamento de como o meio social interfere na produção de uma obra, ressaltando a arte como expressão da sociedade, pois o artista não é neutro às transformações de sua realidade. A leitura da obra literária também irá ressaltar os aspectos culturais que conduzem uma sociedade e estão inseridos na obra. O receptor, no caso o leitor, constitui-se no elo entre o autor e a obra, sem ele a obra não possui sentido, não tem expressão. Nesse contexto, aquele que lê traz no pensamento a realidade lida e a vivida em seu tempo, um choque de comparações que possibilitam a compreensão do texto, que difere 
em leituras posteriores, ou seja, cada momento vivido traz uma experiência de leitura.

Na perspectiva dialética, o meio influencia a obra, a obra influencia o meio, o autor influencia o público e vice-versa. Uma relação tríade e elíptica, necessária à dinâmica da leitura. Nota-se que a obra literária se constitui como um conjunto de fatores, de intencionalidades descritas pelo autor do momento vivenciado, ou ainda, das ficções e sentimentos internos, aprisionados pelo contexto. Sendo assim, a Literatura é a síntese da realidade, na qual o trabalho literário impõe um sentido próprio, imaginário à realidade, não se assemelhando à reprodução mecânica de evidências e fatos, como faz o historiador. $\mathrm{Na}$ Literatura, a leitura de mundo vai além da descrição, ela agrega sentimentos, cores, sentidos, percepções que possibilitam ao leitor regredir ou avançar no tempo. Dessa forma, a Literatura se apresenta como atividade coletiva.

Na dialética de construção do texto literário, a leitura elabora memórias, que elaboram outras memórias, num processo que se refaz a cada leitura. Agregada a essa dinâmica de contribuição com o refazer-se enquanto sujeito de produção, Candido (2008) ressalta a função humanizadora da Literatura. Esse processo, dá-se à medida que a Literatura apresenta uma realidade social e, baseada nela, o leitor passa a compreender melhor o próprio cotidiano.

O leitor, no ato interpretativo, revela os conhecimentos que possui, a sua biblioteca interna de vivências de mundo (ADOLFO, 2007), por isto que a mesma obra terá diferentes sentidos, pois, além da mensagem do autor contida no discurso da história, existem as vivências de cada leitor. Portanto, a leitura pode ser considerada um momento pessoal e identitário, por isto uma história pode fazer chorar e ao mesmo tempo rir (MANGUEL, 2005).

Assim como a sociedade, os livros estão em constante mutação, eles nos revelam as mudanças internas do homem, do cotidiano, do entorno físico e familiar, por esta razão ao reler um livro, a leitura nunca será a mesma, assim como nos alerta Heráclito de Éfeso, filósofo pré-socrático, ao dizer que o homem não se banha duas vezes no mesmo rio, pois o rio não é o mesmo e nem o homem, tudo flui, da mesma forma que o conhecimento em constante movimento de transformação, assim

O conhecimento não consiste no acúmulo de textos ou informações, nem no livro como objeto, mas na experiência resgatada das páginas e novamente transformada em experiência, em palavras que se refletem tanto no mundo exterior como no próprio ser do leitor (MANGUEL, 2006, p. 83). 
A Leitura Literária, além de resguardar a individualidade do leitor, possibilita a compreensão de atitudes estranhas ao nosso contexto, não porque estejamos alheios a eles, mas porque poderiam ser praticadas por nós, seres humanos. Dessa maneira, a Literatura não é libertadora e nem alienadora, ao contrário, contribui com o entendimento da diversidade, pois está atrelada à interpretação individual (MANGUEL, 2006).

Na perspectiva materialista, a análise literária leva em consideração o conteúdo e a forma da obra. No conteúdo, encontra-se primeiramente o estado artístico do autor, considerado pelos escritores o pontapé para a produção. Nesse contexto, a realidade seria a grande base na qual se espelha a obra, sendo ela conhecimento, disponibilizado ao leitor pelo autor, materializado na forma de livro, audiolivros, e-books, em diferentes gêneros textuais. Entretanto, para garantir o sentido e o significado que o autor deseja passar por meio da - ou a partir da - obra, faz-se necessário o estudo da maneira adequada de compor a estrutura linguística, sonora e visual do texto.

[...] o autor de uma obra não é apenas um homem que foi dominado por um estado artístico ou criativo; é também um homem que dominou uma "arte de escrever", uma arte de criar expressão; e compreendemos, finalmente, que não é possível entender em profundidade e julgar com segurança uma obra, sem perceber todos os valores de sua estrutura formal (AMORA, 1917, p. 69).

A Leitura Literária, na perspectiva do materialismo histórico e dialético, permite que o leitor entenda a realidade a partir da análise minuciosa dos aspectos que a configura. Desse modo, o leitor pode perceber as contradições apresentadas na obra em relação aos objetos, fatos ou fenômenos da história, de modo que possa desconfiar e assim problematizar o que está posto pelo paradigma dominante, sendo este processo o princípio básico da dialética (KONDER, 2004). Sem a reflexão do contexto vivenciado, o homem se torna inerte aos acontecimentos, e, assim, de fácil manipulação.

\section{A metamorfose de Franz Kafka}

As transformações sociais e econômicas do início do século XX servem de solo para Kafka ao escrever a obra A metamorfose. Em 1912, ano de escrita da obra, o povo europeu presenciava a iminência da primeira Guerra Mundial. Os movimentos que contribuem para esse disparate humano podem ser percebidos na produção literária do realismo. $\mathrm{O}$ desejo de 
expressar o sentimento de insatisfação, nesse caso, de Kafka, deu origem à transformação do ser humano em um inseto. Biologicamente impossível, $A$ metamorfose, na realidade, faz o leitor refletir acerca de sua condição submissa, indefesa e de perplexidade, perante às instituições que definem e conduzem a vida humana.

A formação em direito de Kafka e seu trabalho em uma companhia de seguros tornamno insatisfeito com a vida, pois o escritor gostaria de se dedicar à Literatura, no entanto, era subvertido ao capital. Atrelada a essa condição de trabalhador, estava sua criação severa pelo pai. Pode-se considerar que esses fatores, aliados à falta de representatividade política na sociedade da época, em conjunto ao seu contexto familiar restritivo, levaram-no ao movimento anarquista e ao desejo de mudança.

No Brasil, um dos maiores estudiosos de Kafka é o professor Modesto Carone. Em uma de suas análises acerca da obra A Metamorfose, intitulada O parasita da família (1992), o estudioso propõe uma análise a partir de uma perspectiva social da história. Nessa análise, dá-se importância ao papel do narrador onisciente que, de forma objetiva narra os fatos da novela, dando um ar sombrio à história, ao demonstrar toda a alienação do ser humano e seu isolamento social.

[...] é justamente essa estratégia artística que articula, no plano da construção formal, a consciência alienada do homem moderno, constrangido a percorrer às cegas os caminhos de uma sociedade de alto a baixo administrada, onde os homens estão concretamente separados não só uns dos outros como também de si mesmos (CARONE, 1992, p. 135).

A incomunicabilidade familiar, primeiro, é advinda dos cinco anos de trabalho escravo da personagem principal, Gregor Samsa, em seguida, é ampliada pela sua transformação em inseto repugnante, do qual os familiares evitavam se aproximar. Essa característica é descrita ao longo da novela pelo personagem Gregor, ao relembrar situações cotidianas vivenciadas em sua casa, desde a época em que ele trabalhava fora de casa e, ao tentar aproximar-se da rotina familiar, enquanto inseto, ao que obtinha como resposta, os desmaios da mãe, a violência do pai e a histeria ao final da história de sua irmã Grete.

Em suma, a história $A$ metamorfose, que na obra em alemão possui o sentido de transformação, conta o absurdo fato ocorrido com a personagem Gregor Samsa, ao ser metamorfoseado em um gigantesco inseto após uma noite de sono intranquilo. É com a 
apresentação do clímax da história, já de início, que Kafka insere o leitor em um mundo que pode ser considerado sombrio, pois o lar apresentado ao leitor difere do sentido romântico de paz e alegria, para ser comparado a uma prisão na qual estão imersos todos os personagens principais.

Enquanto Gregor se pergunta o que teria acontecido com seu corpo, as demais personagens: a mãe, o pai e a irmã se preocupam com o atraso do rapaz ao trabalho. Nota-se que, em determinadas passagens, o próprio Gregor parece estar mais preocupado com o trabalho do que com a sua nova aparência. Ele sabe que é o provedor da casa, aquele que em cinco anos nunca faltara ao serviço, sendo Gregor, o mesmo que conta os dias para a libertação de um trabalho considerado, por esta personagem, massacrante, trabalho advindo da nova condição da família após uma quebra financeira.

Fica subentendido que Gregor paga a dívida do pai com a realização do trabalho e, mesmo sendo bem remunerado, encontra-se desgostoso com sua situação. Esse relato faz parte do primeiro capítulo do livro, que se divide entre a constatação de Gregor da sua condição de inseto, do susto da família ao vê-lo abrir a porta e da fuga do gerente que foi até a casa de Gregor cobrar o atraso dele ao trabalho.

O segundo capítulo dessa novela vai demonstrar o novo tratamento da família a Gregor, a preocupação da irmã com a disposição dos móveis e com a limpeza do quarto (principal ambiente retratado na obra), as tentativas de alimentação do inseto e os cuidados com o filho e irmão nesta nova condição física. Observa-se, nesse capítulo, o predomínio dos cuidados realizados pela irmã, o descaso do pai com o filho e dá-se início às mudanças nos comportamentos das personagens em geral.

De um sentimento de descoberta e assimilação do leitor a respeito da transformação da personagem ocorrida nos dois primeiros capítulos, passa-se à tensão no terceiro capítulo, marcado pela falta de compreensão por parte da família com o filho, pela incomunicabilidade da personagem principal, ocasionando a perda da vontade de entender e querer o bem do outro ser. Nesse processo, o silêncio da dúvida e da incerteza dá lugar ao grito, ao desejo de expulsão, por parte de Grete, bem como, à perda do sentido de viver e à morte de Gregor, que resultam no alívio da família.

Nesse ínterim, o leitor ainda não encontrou respostas ao ocorrido, e não encontrará 
na história toda, entretanto, ficará estarrecido com o desenrolar dos relatos de uma metamorfose dupla: de Gregor Samsa e da família. A personagem principal passa de uma condição humana, provedora, alienada, para a de um parasita, agente improdutivo, empecilho para a família. No entanto, percebe-se que, na condição de inseto, com suas características repugnantes, a personagem parece ter encontrado paz. Desse modo, Gregor tem tempo para refletir acerca de sua condição e pensar a respeito de como era explorado pelo chefe. Apesar de ficar claro que a família também se beneficiava com o trabalho dele, Gregor não demonstra ódio, ao contrário, tem muito carinho por todos e busca compreender inclusive os maus tratos do pai. Ele tem um sentimento especial pela irmã, a quem queria poder falar da intenção de enviá-la a um conservatório para praticar violino.

Pode-se considerar que a personagem possui melancolia ao pensar na família, ao relembrar o convívio e ao querer retomar a condição de provedor. No entanto, não era um sonho, como nos menciona Franz Kafka, a realidade se mostra sombria e perversa para Gregor. A condição de inseto, que mantém suas funções cognitivas, pode ser uma metáfora utilizada pelo autor para a condição humana, na qual são muitos os insetos, milhões na solidão da incomunicabilidade de suas reais condições de sobrevivência. Esse fato pode ser observado nas atitudes da empregada, que é a única que não tem medo da figura monstruosa, por vivenciar essa realidade cruel no seu cotidiano, posto que estava acostumada aos absurdos da vida.

Situação kafkiana é o termo que começou a ser utilizado após a obra A metamorfose para situações surreais, sem explicação racional, uma condição entre o real e o ficcional, muitas vezes advindas das instituições de poder, da qual somos incapazes de compreender seus efeitos nocivos. Nessa obra, a situação kafkaniana começa com a transformação da personagem principal e dos familiares de Gregor Samsa ao rechaçarem a nova forma do filho. O pai que parecia estar sempre cansado, incapacitado, começa a trabalhar no banco e se torna um homem imponente. Somado a isso, advém o fato de que ele esconde um valor em dinheiro que poderia ter reduzido a dívida familiar estimada em mais de seis anos de trabalho do filho. A transformação do pai ganha seu ápice quando ele acerta com uma maça as costas do inseto, o gesto brutal do pai restringe os movimentos do filho, ação que poderia tê-lo matado.

A mãe de Gregor pode ser considerada um ser neutro, pois, ao mesmo tempo em que 
chora e mostra preocupação com o filho, não se esforça, suficientemente, para interagir com o inseto, ela parece ser indiferente ao estado de falta de limpeza e de alimentação inadequadas do filho. A irmã, mais reclusa ao princípio da história, aparentemente um ser frágil, com afinidade para a música, demonstra possuir preocupações com o irmão, pois ela se prontifica a cuidar de Gregor e tem o cuidado de pensar no espaço de circulação do inseto, em seu paladar pela comida, e na higiene do quarto. Com o passar do tempo, parece se cansar com a situação, fica irritada, contrariada com a presença do inseto que parece lhe sugar a felicidade e a oportunidade de aproveitar a vida. Assim, o sentido de parasita da família parece advir das considerações da irmã.

As descrições do quarto, das características do inseto, da casa dos Samsa e sua localização e da rotina do trabalho exaustivo de Gregor possibilitam classificar a obra como integrante do Realismo, no entanto, a história poderia ser considerada transgressora, no sentido de manter traços do Romantismo, ao relatar o amor incondicional de Gregor pela família. Ao mesmo tempo, apresenta indícios do momento vivenciado na "Europa da Belle Époque", ao mostrar o anseio da família ao final da história em usufruir a vida, ir passear e esquecer o vivenciado com o filho.

Os traços que classificam a obra como realista, entretanto, possuem o diferencial da presença do fantástico na obra, advindo da forma absurda na qual o leitor é exposto à nova condição de Gregor Samsa. Sem explicação, o caixeiro viajante é transformado em um inseto e este fato promove o estarrecimento do leitor diante do fato, um estranhamento. Essa transformação pode estar relacionada à vida alienada do trabalhador, submisso às situações desumanas de trabalho, à rotina estressante, condições que retratam a realidade do homem do século XX. Ao leitor cabe a reflexão das atitudes do homem na sociedade atual, questionando-se: "Como estou atuando enquanto ser humano?". Dessa maneira, o leitor é levado para dentro da história, ao refletir as próprias ações e ao buscar uma explicação, já que o autor não as fornece.

A Literatura Fantástica, trabalhada por Marçal (2009), pode ser observada no contexto da personagem de A Metamorfose, quando o leitor é exposto, num ambiente irracional do qual somente a imaginação, ou ainda, a abstração da situação é capaz de dar suporte ao leitor que prossegue a leitura em um transe metafísico. Esse sentimento é função primordial do 
fantástico, no qual ao transcender ao real ela estabelece o absurdo, causando um impacto perturbador da pessoa que lê, ou seja, tira o leitor de sua zona de conforto.

\begin{abstract}
O Fantástico coloca um impasse à razão e não o resolve, retira o indivíduo de sua estabilidade cotidiana e não lhe proporciona, ao final, uma saída racional ou metafísica. Joga-o na zona do "não-sentido" e deixa-o aí, estupefato, paralisado, sem apoio tanto na teologia quanto na ciência. O equilíbrio desta narrativa é tênue e frágil porque ela se instala sobre uma zona fronteiriça, justamente sobre a linha que divide o real e o imaginário, sobre o mistério, a incerteza (MARÇAL, 2009, p. 7).
\end{abstract}

As atitudes diante do fantástico induzem o leitor às seguintes questões diante da primeira e mais aterrorizadora frase da obra: Como assim? Um inseto? Mas, por quê? E em seguida a ânsia por desvendar o mistério, os motivos que levaram o autor a tamanha crueldade, ou, pelo menos, compreender a reação da personagem diante do fato ocorrido, que parece estar distante da gravidade que a envolve. Desse modo, a mescla do fantástico com o realismo, ademais dos traços românticos presentes na obra, entrelaçada aos sentimentos universais, tais como o amor, a compaixão, tornam A Metamorfose uma obra atual que dialoga com os absurdos da vida e com o distanciamento entre os homens.

Percebe-se na sequência da primeira frase da obra a aceitação de Gregor a sua transformação, algo surreal. Vale ressaltar que esse movimento artístico, que teve início na década de vinte, atinge o leitor em primeira instância no caso de A Metamorfose, pois existe a impressão de que Gregor não acordara, ainda continuava em seu sono intranquilo. Desse modo, o autor dá vazão à imaginação e consegue transformar o simples despertar em algo perigoso, características do surrealismo, sendo elas a imaginação e os sonhos. A aproximação com o surrealismo na obra é também percebida no uso das palavras e atitudes da personagem principal, o que reitera a transcendência da obra e a aproxima do movimento modernista. São frases que exprimem força e que impõem um ritmo acelerado ao leitor, conduzindo-o a ler a obra em poucas horas. Situação que se torna possível, pois existe no discurso da história a presença de frases que mexem com os sentimentos e se mesclam com a imagem no imaginário do leitor, de um inseto gigante, que poderia ser reflexo de nosso inconsciente inquietante diante das adversidades da vida.

Observa-se que somente a preocupação com o trabalho é que faz Gregor desejar voltar ao que era antes, pois a vida após a metamorfose parece ser mais amena, o deixa refletir suas 
condições, o amor pelo outro, a enxergar sua situação anterior de trabalho degradante. A ironia da obra advém da própria condição da personagem principal, que se assemelha com a vida real. Dessa maneira, o leitor se insere na história, pois, retirando o absurdo da transformação, os sentimentos da personagem e as atitudes das outras personagens são, em grande parte, um reflexo da vida no século XXI, caracterizada pela desconsideração do sentimento alheio e pelos jogos de interesses, além de ser permeada pelo capital.

Destarte, apesar do momento histórico, aparentemente de bem-estar com as novas tecnologias, a alienação começa a afligir o homem do século XX e o movimento romântico cede espaço para o realismo, que busca retratar esta insatisfação ao descrever as angústias e a realidade humana. Vale lembrar que o autor termina a escrita da obra em 1906, por isto é possível verificar a presença do realismo nessa obra, entretanto, como citado anteriormente, a obra consegue unir passado, presente e futuro ao mesclar tendências literárias.

\section{Determinantes na obra A Metamorfose}

Na perspectiva materialista, o discurso se encontra permeado por intencionalidades, sendo elas um veículo de disseminação de pensamentos do autor. Nessa perspectiva, a leitura é tríade, pois sofre a influência do autor, da obra e do leitor. Desse modo, cada momento histórico-social e as vivências de mundo estão presentes nas obras, assim como são utilizadas pelo leitor no momento da interpretação do texto literário. A partir desse entendimento, autores como Candido (2002) e Manguel (2000) consideram que a Literatura é humanizadora, ao capacitar as pessoas para entenderem as outras, assim como a própria realidade, portanto, a Literatura cumpre papel de reveladora, ao desvelar a sombra que oculta as palavras.

A investigação de cunho materialista-dialética busca no objeto, no caso a obra $A$ Metamorfose, as categorias que representam "a reprodução ideal do movimento real do objeto pelo sujeito que pesquisa" (PAULO NETTO, 2011, p. 21), de modo que possa conhecer na totalidade o objeto e, assim, analisá-lo com rigor, pois somente desta forma é possível conhecer a essência de seu movimento. Para tanto, a pesquisa parte das categorias dialéticas conteúdo e forma. O conteúdo, nesta pesquisa é a história narrada por Kafka de uma personagem que sofre uma transformação profunda não somente em seu físico, mas também em seu psicológico, revelando as contradições presentes no seio familiar em um período 
permeado por instabilidade social e econômica presentes no século $\mathrm{XIX}$ e $\mathrm{XX}$, sendo que muitas ações de insatisfação das relações sociais ainda estão presentes na atualidade. Essa ponte é percebida na forma como a indiferença ao sentimento do outro é crescente nos dias atuais.

A forma, no caso de A Metamorfose, fica por conta do modo como o autor escolheu para transmitir seu conteúdo. A novela que traz logo no início o clímax da história, possui frases concisas sem muitos adjetivos, num tom claro e objetivo. Para maior materialidade dessas duas categorias, a análise busca nos determinantes presentes na obra as contradições que expressem o movimento de escrita do autor, os anseios e a verdade que as palavras, ao princípio ocas, passam da aparência, que oculta seus verdadeiros valores, à essência da escrita.

No caso da obra $A$ metamorfose, a intencionalidade da pesquisa foi investigar os diferentes determinantes: sociais, políticos, econômicos, filosóficos, psicológicos, biológicos, históricos, culturais, estéticos, religiosos presentes na obra, para que se tenha uma dimensão interpretativa maior do que a leitura ingênua dos termos. Tudo isso revela a grandeza de pensamentos utilizados pelo autor no momento da produção dessa novela.

Os determinantes na corrente materialista revelam os fatores ideológicos contidos na palavra, ressaltando desta forma a mensagem que o autor objetiva passar ao leitor ao escrever, ao mesmo tempo que possibilita dar materialidade à obra e às temáticas que são tratadas pelo autor. Esse processo somente é possível com o uso das contradições, da dialética, que possui como ponto de partida a realidade exposta e as adversidades que impossibilitam a personagem de concretizar suas ações. Observar os determinantes e compreendê-los possibilita relacioná-los com os conteúdos científicos historicamente apropriados pelo homem, assim como, subsequentemente, aos fatos, objetos e fenômenos da realidade.

Os determinantes encontrados pelas pesquisadoras na leitura da obra podem ser observados no Quadro 1. Vale ressaltar que o critério para a seleção foi a análise das proximidades que a frase possui com o conceito de cada determinante. Dessa maneira, existe uma linha tênue que os diferencia, além das interpretações subjetivas das pesquisadoras que os classificaram em: Social, Poder, Econômico, Cultural, Afetivo, Estético, Psicológico, 
Biológico, Religioso, Filosófico, Legal e Climático. A classificação tem o objetivo de perceber as intencionalidades da mensagem que o autor buscava transmitir ao produzir a obra, e desta maneira, demonstrar o momento histórico-social e as características da sociedade na qual Kafka participava. A pesquisa buscou, ao mesmo tempo, fragmentar os determinantes, num processo de análise, de aprofundamento do conhecimento, tendo como base o método dialético de Marx. Esse movimento busca compor a totalidade da análise, que seria a unidade da diversidade, categoria fundamental do método e que representa uma das bases do edifício teórico de Marx, que ainda conta com a contradição e a mediação.

Quadro 1 - Determinantes presentes na obra A metamorfose de Franz Kafka

\begin{tabular}{|c|c|}
\hline DETERMINANTE & QUANTIDADE \\
\hline Social & 19 \\
\hline Poder & 19 \\
\hline Econômico & 17 \\
\hline Cultural & 12 \\
\hline Afetivo & 12 \\
\hline Estético & 10 \\
\hline Psicológico & 10 \\
\hline Biológico & 8 \\
\hline Religioso & 6 \\
\hline Filosófico & 4 \\
\hline Legal & 2 \\
\hline Climático & 2 \\
\hline Histórico & 1 \\
\hline
\end{tabular}

Fonte: As pesquisadoras.

No Quadro 1, estão expostos os determinantes presentes na obra sob a perspectiva das pesquisadoras. Nota-se o predomínio do determinante social e de poder, seguidos pelo econômico, cultural, estético e psicológico. Percebe-se que eles fornecem o tom da obra, carregada do desvelamento de uma sociedade que sofre com a imposição do capital, uma realidade que oprime o homem do século XX. A questão afetiva fica por conta da personagem principal, que demonstra gratidão, amor, consideração, preocupação com os familiares. No entanto, a família corresponde a esse afeto apenas no princípio da história, pois na sequência trata a personagem com descaso e indiferença. Para conhecer supostamente as intencionalidades do autor ao escrever a obra, a pesquisa aponta alguns dos determinantes identificados, sendo eles os mais representativos.

Na leitura da obra de Kafka, os determinantes mais presentes são o social e o de poder. 
Os trechos com a presença do determinante social retirados da obra denotam o cotidiano das personagens, como a presença da empregada nos lares "A seguir, a criada foi à porta, como de costume, com o seu andar pesado e abriu-a" (KAFKA, 2018, p. 5). Em seguida, percebe-se o social na condição dos empregados, trabalhadores, neste caso de caixeiro-viajante, e o pensamento capitalista de aproveitar ao máximo a mais valia do trabalhador e a consideração desconfiada dos padrões em relação ao comportamento dos trabalhadores ao mencionar a possibilidade de malandragem em seus comportamentos, "Seria que todos os empregados em bloco não passavam de malandros, que não havia entre eles um único homem devotado e leal que, tendo uma manhã perdido uma hora de trabalho na firma ou coisa parecida [...]" (KAFKA, 2018, p. 5). A contradição social presente nesses trechos se refere à manutenção da empregada na casa apesar da situação financeira precária da família, como se ela representasse um status, uma condição social superior as demais famílias. Não existia a necessidade de uma empregada, já que havia três pessoas que não possuíam um vínculo empregatício na casa, situação que se inverte ao final da história. A relação social de superioridade também é refletida na relação entre trabalhador e patrão, como se o empresário fosse o dono da verdade, o ente da razão. Esse determinante possibilita o viés da discriminação social presente na realidade laboral da sociedade capitalista atual.

Outro trecho social de destaque está presente logo no início da obra, é a demonstração de apego familiar da personagem principal, quando alega que "Gregório estava ainda em casa e nem por sombras pensava em abandonar a família" (KAFKA, 2018, p. 7). Observa-se com o determinante social a atitude dos empregados diante dos patrões, sendo este comportamento uma questão de honra, no qual ao assumir um compromisso, o homem o cumprirá a todo custo, "Tenho uma dívida de lealdade para com o patrão, como o senhor bem sabe" (KAFKA, 2018, p. 10).

Nota-se que a presença desse determinante na obra possui a função de ressaltar a influência das relações sociais na formação humana, além de fornecer a materialidade desse determinante, seja no convívio familiar, seja no ambiente laboral. Nota-se que, na sociedade atual, essa realidade ainda persiste e é responsável pela falta de comunicação, e no caso de Gregor proporciona o isolamento, estando ele à margem do diálogo dos familiares e envolto na falta de compreensão. No caso atual da classe de trabalhadores e a burguesia, observa-se 
o acirramento das relações, de modo a prejudicar as condições de trabalho.

O determinante de poder possui destaque na obra. Ele pode ser observado na visita do gerente à casa de Gregor após um atraso em cinco anos de trabalho "Eu que tentasse sequer fazer isso com o meu patrão: era logo despedido" (KAFKA, 2018, p. 2). O receio de contrariar a autoridade do patrão está presente em vários momentos, principalmente no início da obra, "E, mesmo que apanhasse o trem, não conseguiria evitar uma reprimenda do chefe" (KAFKA, 2018, p. 3). O determinante de poder está presente na relação familiar, na transformação do pai que, de um velho cansado, passa a um senhor com muito vigor e total impaciência com o filho, demonstrada com o uso da violência "Foi então que o pai lhe deu um violento empurrão, que constituiu um verdadeiro alívio, e Gregório voou até o meio do quarto, sangrando abundantemente" (KAFKA, 2018, p. 12). A irmã de Gregor, ao final da história, colabora com a humilhação da nova condição do irmão ao exigir dos pais um posicionamento diante da situação de estranhamento ao parasita "Não pronunciarei o nome do meu irmão na presença desta criatura e, portanto, só digo isto: temos que ver-nos livres dela" (KAFKA, 2018, p. 30).

O poder, nesse caso, advém do predomínio de opressão exercida à personagem, seja ela do trabalho exaustivo, escravo, como também familiar, nas atitudes do pai. Estudiosos da vida do autor consideram que as passagens de opressão do pai de Gregor na história podem ter como base a educação de Kafka, que viveu a opressão do pai rigoroso. A questão de poder pode definir o momento histórico vivenciado pelo autor, no qual as instituições de domínio determinavam a insurgência da Primeira Guerra Mundial, algo absurdo, como a metamorfose. Esse fato reflete a falta de compreensão entre as pessoas e a insatisfação de um período histórico mundial das instâncias políticas, o imperialismo, e suas ganâncias por mais territórios.

A contradição no caso desse determinante advém do fato de que quanto mais amor, tentativas de contato, de valorização pessoal da personagem, mas ela recebia dos familiares e do patrão o desprezo, pois o determinante neste processo possui um sentido negativo de desvalorização do outro. Observa-se a materialidade do sentimento de rejeição proporcionado pelo determinante de poder advindo daquele que se sente superior ao outro, seja pelo trabalho que executa ou pela função que exerce em casa, gerada principalmente 
pelo condicionante econômico, presente na obra e nos dias atuais.

Outro determinante predominante na obra é o econômico. Aliás, Gregor desde o começo da novela possui a preocupação com a renda familiar, principalmente, com a dívida de trabalho que contraiu após a queda financeira do pai: "Bem, ainda há uma esperança; depois de ter economizado o suficiente para pagar o que os meus pais the devem - o que deve levar outros cinco ou seis anos" (KAFKA, 2018, p. 3). E "Por ele não se levantar e não abrir a porta ao chefe de escritório, por ele estar em perigo de perder o emprego e porque o patrão havia de começar outra vez atrás os pais para eles pagarem as velhas dívidas?" (KAFKA, 2018, p. 7). O determinante econômico percorre toda a história, primeiro ao definir a condição de escravo de Gregor e, depois, com a situação da família que passa a depender dos novos empregos para sobreviver "Logo no primeiro dia, o pai explicara a situação financeira e as perspectivas da família a mãe e irmã" (KAFKA, 2018, p. 16).

O determinante econômico conduz à dissolução da família que a princípio possui Gregor como seu provedor, e depois a própria família passa a conquistar seu espaço no mercado de trabalho, considerando o filho um parasita, já que não produz, como a maioria dos insetos, apenas consome. No caso de Gregor, primeiro ele consome o espaço familiar, depois o tempo e, finalmente, o psicológico dos familiares. Com esse determinante o autor ressalta a influência do econômico nas relações sociais, em especial, nas envoltas com a alienação, nas quais o Ter é superior ao Ser. Assim como na história, as relações sociais atuais compactuam de um pensamento individualista advindas, em sua maioria, da disseminação da ideologia da classe dominante, na qual a pessoa é reconhecida pelos seus bens e não por suas ações. Nota-se que não houve transformação do homem no que concerne a aproximar-se daquele que pode lhe trazer um benefício financeiro, isto demonstra que devemos investir nas relações sociais de maneira a buscar a emancipação do homem para estruturas além do capital.

A respeito do uso do determinante cultural, o autor buscou mostrar ao leitor a influência dele na constituição dessa sociedade que passava por transformações, de um período anterior, ligado ao romantismo, ao sentimento de obscuridade do realismo e o da liberdade com a Belle Époque e o advento da tecnologia. No entanto, essas transformações resultaram na insatisfação do homem devido à alienação das novas formas de produção. 0 
determinante cultural possibilita ao leitor conhecer os costumes da época de produção, os encontros familiares na sala de estar, o costume da leitura entre os familiares "Através da fenda da porta, verificou que tinham acendido o gás na sala de estar. Embora àquela hora o pai costumasse ler o jornal em voz alta para a mãe e eventualmente também para a irmã [...]" (KAFKA, 2018, p. 13). As cenas do cotidiano são expressas em diversos momentos na obra, tais como alimentação dos mais pobres, "Passavam pelas piores provações que o mundo impõe aos pobres; o pai ia levar o pequeno almoço aos empregados de menor categoria do banco [...]" (KAFKA, 2018, p. 25), como também o uso de certas vestimentas "Chegados ao vestíbulo, recolheram os chapéus e as bengalas, fizeram uma vênia silenciosa e deixaram a casa" (KAFKA, 2018, p. 33).

As relações afetivas da obra entram em contradição ao sugerir uma família preocupada com o ente provedor que vai ao encontro do retrato típico familiar da época, descrito nos manuais de história, no entanto Kafka busca enfatizar que essa realidade não está presente em todos os lares. Em situações de desumanização, como em períodos próximos da guerra, o instinto de sobrevivência revela atitudes inesperadas nos homens. A característica realista da obra proporciona esse desvelamento das reais relações sociais, e a contradição deixa os leitores estarrecidos, diante de cada ação de desamor dos familiares.

O determinante afetivo possibilita ao leitor entender as transformações e as contradições ocorridas com a família. A princípio, mostram-se fraternais com Gregor e depois são displicentes e incorrem até no ato de abandono. "O rapaz não pensa senão no emprego. Quase me zango com a mania que ele tem de nunca sair à noite [...]" (KAFKA, 2018, p. 6); “Deixem-me ir ver o Gregório, o meu pobre filho!” (KAFKA, 2018, p. 18). Percebe-se que Gregor mantém seus sentimentos de amor aos familiares, reconhece o auxílio da irmã, "Este acontecimento revelou a Gregório a repulsa que o seu aspecto provocava ainda à irmã e o esforço que devia custar-Ihe não desatar a correr mal via a pequena porção de seu corpo que aparecia sob o sofá" (KAFKA, 2018, p. 18).

O determinante psicológico é outro que possui destaque na obra. Esse determinante aponta as contradições das personagens que parecem reagir de forma adversa ao que o leitor espera. O desejo do autor em desestruturar a leitura, a partir da apresentação de comportamentos considerados não tradicionais, vai de encontro a um período de 
transgressão à cultura estabelecida, ao desejo de mudança, ou ainda, ao próprio medo da situação de instabilidade de uma possível guerra. Entretanto, na sociedade atual, a materialidade desse determinante revela pessoas frágeis, dependentes do grupo social do qual participam. No caso de Gregor, ele pode ser considerado vítima de uma situação psicológica adversa, que o surpreendia, assim como ao leitor, em vários momentos.

A partir do parâmetro psicológico é possível perceber a mudança de sentimentos dos personagens diante da metamorfose. O absurdo da transformação afeta diretamente a vida de todos na casa dos Samsa, a única que parece ser imune ao acontecimento é a empregada, que inclusive se diverte com a situação, dando à personagem a característica de fria, cruel. No entanto, pode-se considerar que, na realidade da empregada, os absurdos devem ser uma constante.

Vale ressaltar que o determinante psicológico na obra atinge diretamente o leitor já na primeira frase da novela, ao apresentar uma situação considerada fantástica, a transformação de um homem em inseto "Numa manhã, ao despertar de sonhos inquietantes, Gregório Samsa deu por si na cama transformado num gigantesco inseto" (KAFKA, 2018, p. 1). A partir da metamorfose, as personagens estão em constante conflito: da falta de comunicação, de distanciamento afetivo, "Se ao menos pudesse falar com ela e agradecer-Ihe tudo o que fazia por ele" (KAFKA, 2018, p. 17). Assim como, a luta pela sobrevivência financeira e o desgaste físico fizeram a irmã considerar que "Tem é de tirar da cabeça a idéia de que aquilo é o Gregório" (KAFKA, 2018, p. 30).

A estética está presente na obra pela forma com que o autor constrói suas frases com um discurso direto e objetivo, fica claro que este modo de escrever se contrapõe a grande parte de outros romances da época, pois apresenta o clímax ao princípio da obra. A contradição dessa obra em relação a outras está na realidade que ela proporciona ao leitor desde o princípio, situações absurdas, assim como ocorre na vida, uma situação de desemprego, por exemplo, que exige do trabalhador atitudes de mudar de função.

Nota-se que esse determinante possibilita ao autor descrever tanto a nova forma física da personagem Gregor, "Estava deitado sobre o dorso, tão duro que parecia de metal e, ao levantar a cabeça, divisou o arredondado ventre castanho dividido em duros segmentos arqueados [...]" (KAFKA, 2018, p. 2), ao descrever as perninhas do inseto, o casco duro 
inflexível, a posição do pescoço em algumas situações, fazendo que o leitor possa se sentir um pouco no lugar de Gregor, quanto a casa da personagem, o ambiente principal da obra, principalmente o quarto, considerado o ambiente mais descrito na história, dando à novela o realismo de uma sociedade considerada supérflua, "a cômoda onde guardava a serra de recorte e as outras ferramentas tinha sido retirada, e agora tentavam remover a secretária, que quase parecia colada ao chão [...]" (KAFKA, 2018, p. 20). A imponência do pai também é descrita "[...] firme, envergando uma bela farda azul de botões dourados, [...] vigoro duplo queixo espetava-se para fora da dura gola alta do casaco e, sob espessas sobrancelhas, brilhavam-Ihe os olhos pretos, vívidos e penetrantes" (KAFKA, 2018, p. 22).

A corrente realista na qual a obra se insere é destacada também pelo determinante biológico. No Brasil, as obras de cunho realista, tais como O cortiço, de Aluísio Azevedo, e Mémórias Póstumas de Brás Cubas, de Machado de Assis, também utilizaram o biológico para surpreender o leitor e causar certa repugnância ao ambiente e suas personagens. Essa reação ao ser biológico, que traz a vida em seu cerne, somente é superada com os atos do ser social, mais complexo que o ser biológico, para Marx (PAULO NETTO, 2011), e com especificidades infinitas. Para dar maior realidade à obra, o autor, em vários trechos, recorre às descrições de necessidades biológicas fundamentais de sobrevivência do homem e do inseto, dando maior realidade aos fatos, considerando as necessidades humanas relevantes, tais como: "Um homem necessita de sono" (KAFKA, 2018, p. 2), ou ainda, "Efetivamente, Gregório sentia-se bem, à parte uma sonolência que era perfeitamente supérflua depois de um tão longo sono, e sentia-se mesmo esfomeado" (KAFKA, 2018, p. 3). No final da novela, o determinante estético possibilita ao leitor aproximar-se do desfecho da personagem ao relatar as sensações do momento, "Depois, a cabeça pendeu-Ihe inevitavelmente para o chão e soltou-lhe pelas narinas um último e débil suspiro" (KAFKA, 2018, p. 32).

Percebe-se que o biológico está voltado à descrição das necessidades físicas do homem, ao estado biológico do inseto, às limitações da nova estrutura física de Gregório e aos momentos finais de sua vida. Essas inserções fornecem para a história maior realidade, pois são condições primárias da vida. Essa quase denúncia do autor, dos maus tratos familiares, estão presentes na sociedade atual, na desconsideração de acesso às condições básicas, necessárias à vida, como ocorre com a área da saúde. Uma sociedade que renega as 
condições básicas para a vida como saúde, saneamento básico, educação. Para Marx e Engels (2015) o desenvolvimento humano deu-se historicamente pela luta de classes entre a classe dominante e a classe dominada. Essa luta expressa sempre o descaso daqueles que possuem como ferramenta apenas a força de trabalho, menosprezando suas necessidades básicas de saúde, educação e segurança.

Outro determinante que possibilita ao leitor entender o porquê de a família Samsa aceitar tão prontamente a metamorfose e passar, a princípio, a cuidar do inseto é o religioso, com exclamações que fornecem à novela uma entonação de surpresa diante do absurdo: “Diabos levem tudo isso!” (KAFKA, 2018, p. 2); “Ai, meu Deus! Ai, meu Deus! - e deixou-se desmaiar de braços abertos no sofá, não dando mais sinal de vida" (KAFKA, 2018, p. 21). Entretanto, esse mesmo determinante redime o modo de tratamento ao filho no final da história e exprime o alívio pelo término de um considerado pesadelo, "Muito bem-disse o Senhor Samsa -, louvado seja Deus (KAFKA, 2018, p. 32)”, possibilitando que a família seguisse seus sonhos, suas vidas. O determinante religioso para o marxismo possui a função veladora da verdade. Isso ocorre no momento que se utiliza da justificativa divina para certas ações humanas. No caso da última frase citada da obra, o desejo de morte de Gregor era um desejo da família e não divino, pois são os homens que produzem a religião, segundo Marx (2005). A contradição nesse caso está em atribuir um desejo humano a uma entidade divina. A religião atua na obra como pano de fundo para ações irracionais dos familiares da personagem principal.

No caso do determinante filosófico, percebe-se que o autor o utiliza como forma de reflexão das ações das personagens, principalmente do próprio Gregório "Ao mesmo tempo, não se esquecia de ir recordando a si mesmo que era muito melhor a reflexão fria, a mais fria possível, do que qualquer resolução desesperada (KAFKA, 2018, p. 5). O determinante conduz as reflexões da personagem principal acerca de seu novo estado físico "Poderia ser realmente um animal, quando a música tinha sobre si tal efeito?" (KAFKA, 2018, p. 28).

O determinante filosófico na obra traz a contradição entre o bem e o mal. A reflexão acerca das características pelas quais é possível nos visualizar como humanos estão em linha tênue na obra. Ser humano para Kafka seria amar o outro sem interesses financeiros, sem estigmatizar o outro pela aparência que possui. Indaga-se ao longo da leitura da obra: Seria o 
ser humano movido pelo interesse financeiro? Nesse caso específico, a família estaria sujeita também ao interesse econômico? Como justificar a falta de consideração com o ente familiar?

Para Mészáros (2007), o processo de internalização na sociedade do discurso da classe dominante interfere na transformação de um mundo mais uniforme, mais justo. A educação formal contribui para esse processo, no entanto cabe a ela, juntamente com a sociedade como um todo, uma formação para além do capital, para a vida, para a emancipação humana com a igualdade de direitos e deveres, para uma sociedade mais justa.

A solidão da personagem principal reflete, em parte, a história do autor, Franz Kafka, que foi criado por empregados, e via no pai a expressão do autoritarismo e na mãe, a timidez. Os personagens Sr. Samsa e Sra. Samsa, ambos sem nome definido, possuem em parte a identidade dos pais de Kafka. A criação mais próxima com os irmãos é revelada na personagem de Grete, a única que se prontifica a cuidar do inseto.

Após a transformação, a permanência do cognitivo no inseto não distancia Gregor da história, é ele que pensa, reflete, sente, observa, imagina o futuro, tem desejos. No entanto, não lhe escutam. Somente a razão sem a ação, como é o caso de Gregor, constitui-se um dos pilares do movimento anarquista do qual Kafka era integrante. Essas proximidades entre obra e autor tornam a investigação das intencionalidades mais profundas.

Continuando com a análise dos determinantes, no caso do legal, ele pode ser observado em duas citações na obra. Uma, na qual expressa o poder do patrão com o uso do médico representante da Previdência que daria o aval para a suposta enfermidade de Gregor, “O próprio patrão certamente iria lá na casa com o médico da Previdência, repreenderia os pais pela preguiça do filho e poria de parte todas as desculpas [...]" (KAFKA, 2018, p. 3). E outra, no final da história, no momento em que a família Samsa busca se justificar perante os patrões com relação à falta ao trabalho que descreve a seguinte situação: "[...] escreveram três cartas de justificação de ausência: o Senhor Samsa à gerência do banco, a Senhora Samsa à dona da loja para quem trabalhava e Grete ao patrão da firma onde estava empregada" (KAFKA, 2018, p. 33).

Desde muito jovem, Marx percebia que existiam forças que incapacitavam as pessoas de conquistarem seus objetivos. Em outros momentos de sua vida, Marx teve seu direito de expressar-se criticamente impedido, o que resultou em sucessivos exílios. Mais tarde, com sua 
teoria social mais aprofundada percebeu que o direito representado pelo Estado vinha a beneficiar a classe dominante (KONDER, 1968). Na obra A Metamorfose, o autor busca com o uso do determinante legal expressar a contradição da liberdade dos que possuem apenas a força de trabalho, eles são cerceados no direito de ir e vir, somente o podem fazer com a autorização dos seus considerados superiores.

No caso do determinante histórico, o autor utiliza os momentos de reflexão de Gregor para inserir o passado de forma melancólica. O passado que Ihe trazia alegrias, uma alegria familiar, não trabalhista, diferentemente do presente, que pode ser considerado a concretização de um pesadelo, "É certo que faltava às suas relações com a família a animação de outrora, que sempre recordara com certa saudade nos acanhados quartos de hotel em cujas camas úmidas se acostumara a cair [...]" (KAFKA, 2018, p. 24). A presença do histórico na obra serve como base para os sentimentos da personagem para com seus familiares. Marx (2017) considera a história o alicerce de suas investigações e quem as movimenta são as contradições presentes na realidade dos homens. Para entender a realidade é preciso fazer esse processo de retomada do histórico, de modo a reafirmar posicionamentos, constatações. O método de análise dialético de Marx possui como ponto de partida o objeto mais desenvolvido, no caso da investigação de Marx é a produção da sociedade burguesa. Já no caso de Kafka o momento atual da personagem Gregor era o de sua metamorfose.

O ar sombrio da novela não está somente na transformação de Gregor, ou ainda, nas atitudes familiares, mas também com o uso do determinante climático que leva o leitor a sentir a nuvem presente nos olhos de Gregor e uma suposta esperança de retornar ao seu estado físico anterior, "[...] sete horas, e um nevoeiro tão denso, por momentos, deixou-se ficar quieto, respirando suavemente, como se porventura esperasse que um repouso tão completo devolvesse todas as coisas à sua situação real e vulgar" (KAFKA, 2018, p. 5). Em outro momento, a novela traz esse sentimento de adversidade explícita pelo clima, "Nessas alturas, tentava focar a vista tão distintamente quanto podia na janela, mas, infelizmente, a perspectiva da neblina matinal, que ocultava mesmo o outro lado da rua estreita, pouco alívio e coragem Ihe trazia" (KAFKA, 2018, p. 5).

Os determinantes possuem o objetivo de criar as contradições de modo que se possa dar materialidade ao objeto da realidade, assim é utilizado o climático na obra. Entre a opção 
de descrever dias ensolarados e quentes com poucas nuvens e um céu azul, o autor optou por um ambiente sombrio, assim como estão os sentimentos das personagens, de mesmo modo que a situação absurda da metamorfose, momento inexplicável e sem perspectivas de mudança. A fragmentação em diferentes determinantes presentes na obra possui o objetivo de observar as contribuições de cada um para o entendimento da totalidade da obra, assim como o faz Marx (2017) ao construir seu método para a análise da sociedade burguesa, na qual parte de diferentes categorias e seus determinantes de modo a entender o movimento real.

Ler a obra pela perspectiva dos determinantes possibilita uma investigação mais densa do momento histórico da produção, assim como amplia a visão global do leitor acerca da obra, desta maneira a leitura se torna um processo interligado entre o contexto de produção, as intencionalidades do autor e a história em si. Esse fato enriquece o entendimento da realidade do leitor e faz da leitura um modo de obtenção de conhecimento. Também possibilita ao leitor a reflexão da atualidade das temáticas abordadas por Kafka nessa obra.

Para a Educação, a leitura mediada pela análise dos determinantes possibilita o pensar criticamente cada pormenor da obra literária, descontruindo a alienação do pensamento e o mundo de fetiche, do Ter sobre o Ser, da realidade advinda do discurso manipulador da classe dominante, ou seja, da aparência em contraposição ao mundo da essência, conforme nos orienta Silva (2005). Desse modo, cabe à Educação uma análise mais profunda de seu papel revelador da alienação e o uso de instrumentos pedagógicos, tais como a Literatura

\section{Considerações finais}

A Leitura Literária pode ser considerada um instrumento de percepção da realidade, contribuindo com a mudança de pensamento dos homens. Seria uma maneira de constituir novas atitudes, novos caminhos, novos olhares que visam à constituição do caráter, da compreensão do outro, das diferenças, das culturas.

O absurdo da obra $A$ metamorfose talvez não esteja na transformação de um homem em um inseto, mas na forma como ele era subjugado pela família bem como pelo contexto social e econômico da época. Nota-se que a derrocada da personagem principal advém dos 
entes familiares que, a princípio, o criaram e, ao final, acabaram por destruí-lo.

Várias são as contribuições de obras literárias como a escrita por Kafka. Primeiro, essa obra colabora para que se compreenda o pensamento do homem naquele período histórico, o sentimento de repúdio à nova configuração de alienação e fragilidade do ser humano. Segundo, porque serve como meio de reflexão para o homem atual, do século XXI, que continua perdendo sua essência humana em nome da aparência, da busca pelo conforto material somente.

O recurso de fragmentar a obra em determinantes possibilita ao pesquisador e ao leitor verificar quais os parâmetros da realidade que serviram como solo para o conteúdo que foi exposto pelo autor. Dessa maneira, percebe-se a riqueza da obra A metamorfose, a partir de sua totalidade revelada na essência, que apresenta as contradições de cada determinante.

A Educação necessita desse exercício de aprofundamento de seus conteúdos, oportunizando ao aluno conhecer a historicidade, as especificidades dos objetos, fatos ou fenômenos, dando margem para a reflexão crítica das ações humanas que devem ser transformadoras, visando a emancipação do homem. A Literatura permite essa ação ao revelar contextos como os de $A$ Metamorfose, nos quais as relações sociais se encontram fragilizadas, e perceber que essas ações pouco se alteraram no momento atual, no qual o distanciamento humano fornece parâmetros para ações de descaso com as necessidades básicas não só de saúde, educação e segurança, mas também de valores humanos. 


\section{Referências}

ADOLFO, S. P. Literatura e visão de mundo. In: REZENDE, L. A. (org.) Leitura e visão de mundo: peças de um quebra-cabeça. Londrina: EDUEL, 2007. p. 25-36.

AMORA, A. S. Teoria da Literatura. São Paulo: Crítica Literária, 1917.

CANDIDO, A. Literatura e sociedade. 10. ed. São Paulo: Ouro sobre azul, 2008.

CANDIDO, A. Textos de intervenção. São Paulo: Editora 34, 2002.

CARONE, M. O parasita da família (sobre "A Metamorfose" de Kafka). São Paulo: Psicologia USP, v. 3, n. 1-2, 1992. Disponível em:

http://pepsic.bvsalud.org/scielo.php?script=sci_arttext\&pid=S1678-51771992000100013. Acesso em: 20 maio de 2018.

FRANCO, S. A. P.; OLIVEIRA, R. M. G. A Literatura como atividade investigativa para a superação do cotidiano. Nuances: estudos sobre Educação, Presidente Prudente-SP, v. 27, n. 2, p. 97-115, mai./ago. 2016. Disponível em:

http://dx.doi.org/10.14572/nuances.v27i2.3647. Acesso em: 24 jul. 2018.

FRANCO, S. A. P.; FERNANDES, G. F. G. MAFALDA: possibilidades de leitura na perspectiva histórico-crítica. Revista Educação e Cultura Contemporânea. v. 13, n. 34, p. 145-161, 2017. Disponível em:

http://revistaadmmade.estacio.br/index.php/reeduc/article/viewFile/1008/1511. Acesso em: 24 jul. 2018.

GALVÃO, R. M.; SILVA, R. F.; DIA, V. A. T.; FRANCO, S. A. P. Atividades de intervenção com o uso do gênero charge para o ensino de Geografia na Educação Básica. Revista Educ. Anál., Londrina, v. 2, n. 1, p. 176-194, jul./dez. 2016. Disponível em:

http://www.uel.br/revistas/uel/index.php/educanalise/article/view/27116. Acesso em: 24 jul. 2018.

KAFKA, F. A Metamorfose. 2018. Disponível em:

http://www.dominiopublico.gov.br/download/texto/ua00106a.pdf. Acesso em: 10 jun. 2018.

KONDER, L. O que é a dialética. São Paulo: Brasiliense, 2004. Coleção primeiros passos.

KONDER, L. Marx: vida e obra. Rio de Janeiro: José Álvaro Editora S/A, 1968. Coleção Vida e Obra.

MANGUEL, A. Os livros e os dias: um ano de leituras prazerosas. São Paulo: Companhia das Letras, 2005.

KONDER, L. A biblioteca à noite. São Paulo. Companhia das Letras, 2006.

KONDER, L. No bosque do espelho: ensaios sobre as palavras e o mundo. São Paulo:

Companhia das Letras, 2000.

MARÇAL, M. R. A tensão entre o fantástico e o maravilhoso. Fronteira Z, v. 3, n. 3, p. 1-8, 2009. Disponível em: https://revistas.pucsp.br/index.php/fronteiraz/article/view/12541. Acesso em: 20 jun. 2018. 
MARX, K. Crítica da Filosofia do Direito de Hegel. São Paulo: Boitempo, 2005.

MARX, K. O capital: crítica da economia política. Livro I: o processo de produção do capital. Tradução Rubens Enderle. 2. ed. São Paulo: Boitempo, 2017.

MARX, K.; ENGELS, F. Manifesto do partido Comunista. 3. ed. Tradução Edmilson Costa. São Paulo: Edipro, 2015.

MÉSZÁROS, I. O desafio e o fardo do tempo histórico: o socialismo no século XXI. Tradução Ana Cotrim e Vera Cotrim. São Paulo: Boitempo, 2007.

PAULO NETTO, J. Introdução ao estudo do método de Marx. São Paulo: Expressão Popular, 2011.

SILVA, J. C. Educação e Alienação em Marx: contribuições teórico metodológicas para pensar a história da educação. Revista HISTEDBR On-line, Campinas, n. 19, p. 101-110, set. 2005.

Disponível em: https://www.fe.unicamp.br/pf-fe/publicacao/4826/art07_19.pdf. Acesso em 03 nov. 2018.

Recebido em: 28/07/2018

Aprovado em: 21/11/2018 